\title{
Aberrant promoter hypermethylation of the CHFR gene in oral squamous cell carcinomas
}

\author{
SEIJI BABA ${ }^{1}$, AKIRA HARA ${ }^{2}$, KEIZO KATO $^{1}$, NGUYEN KHANH LONG ${ }^{1}$, YUICHIRO HATANO ${ }^{2}$, \\ MASASHI KIMURA $^{3}$, YUKIO OKANO ${ }^{3}$, YASUHIRO YAMADA ${ }^{2}$ and TOSHIYUKI SHIBATA ${ }^{1}$ \\ Departments of ${ }^{1}$ Oral and Maxillofacial Sciences, ${ }^{2}$ Tumor Pathology, ${ }^{3}$ Molecular Pathobiochemistry, \\ Graduate School of Medicine, Gifu University, 1-1 Yanagido, Gifu 501-1194, Japan
}

Received May 20, 2009; Accepted July 1, 2009

DOI: $10.3892 /$ or_00000552

\begin{abstract}
Recent studies have shown that promoter hypermethylation of tumor suppressor genes is an important factor in carcinogenesis of several human organs. The purpose of this study was to examine the methylation status of CHFR, a novel cell cycle regulatory gene, in both primary oral cancer tumors and the adjacent normal mucosa, and to clarify the relation between the methylation status and expression of the CHFR-related chromosomal passenger protein Aurora-A. The methylation status of the CHFR gene was examined by the methylation-specific PCR (MSP) in 49 primary oral squamous cell carcinomas (OSCC) and 6 OSCC cell lines. In 13 cases, the adjacent normal oral mucosal tissues were also examined. Normal oral mucosa from 18 healthy volunteers was used as the control. The mRNA level of Aurora-A and CHFR in OSCC cell lines was investigated by real-time RT PCR and the protein expression of Aurora-A in certain tumor samples was confirmed by immunohistochemistry. Aberrant promoter methylation of the CHFR gene was detected in $34.7 \%$ (17 of 49) of OSCC cases. As for the 13 OSCC cases with paired cancerous and adjacent normal tissues, promoter hypermethylation of the CHFR gene was detected in $46.1 \%$ (6 of 13 ) of the cancerous tissues. In contrast, promoter hypermethylation of the CHFR gene was recognized in only $7.7 \%$ (1 of 13) of the surrounding normal mucosa. No hypermethylation of the CHFR gene was detected in healthy volunteers. Only one OSCC cell line shows hypermethylation of the CHFR gene with concurrently silenced mRNA expression, however, Aurora-A was expressed abundantly in all cell lines. Furthermore, there is no significant relationship between methylation status of the CHFR gene and Aurora-A protein expression in OSCC. Hypermethylation of the CHFR
\end{abstract}

Correspondence to: Dr Akira Hara, Department of Tumor Pathology, Graduate School of Medicine, Gifu University, 1-1 Yanagido, Gifu 501-1194, Japan

E-mail: ahara@gifu-u.ac.jp

Key words: CHFR, oral squamous cell carcinomas, hypermethylation, aurora, normal mucosa gene was detected in a certain part of OSCC cases whereas it had very low frequency in adjacent normal oral tissues. Although further study is needed, Aurora-A gene expression seems to be independent from methylation status of the CHFR gene in OSCC.

\section{Introduction}

Squamous cell carcinoma accounts for $\sim 90 \%$ of oral cancer (1). Oral squamous cell carcinoma (OSCC) is the eleventh most common types of human cancer worldwide (2). In Japan, OSCC is relatively common, accounting for $>9,600$ new patients in 2001 and $~ 5,600$ deaths in 2005 (3). In OSCC, the promoter hypermethylation of many tumor suppressor genes has been reported $(4,5)$.

CHFR, checkpoint with fork head-associated and RING finger, is a recently identified gene, localized to chromosome 12.q24.33. CHFR encodes FHA domain and RING finger domain, which functions as an important checkpoint protein early in G2-M transition. The mitotic checkpoint genes (6), which prevent entry into cell cycle, are rarely inactivated in human cancer. However, the CHFR gene, which is a checkpoint that delays entry into metaphase in response to mitotic stress, is inactivated owing to lack of expression or by mutation (7). CHFR works as an E3 ubiquitin ligase and induces the proteasome-dependent degradation of Plk1 (8) and Aurora-A (9). Mouse embryonic fibroblasts (MEF) derived from $C h f r$ knockout mice model show elevated protein levels of Aurora-A and display chromosome abnormalities (9). The inactivation of the CHFR gene may upregulate these mitotic kinases and are overexpressed in human malignant tumors (10). In normal human cells, CHFR are delayed in entering mitosis in the presence of mitotic stress.

CHFR is frequently downregulated in human cancers, mostly owing to the hypermethylation of its promoter region. CHFR downregulation has been found in primary cancers or in the established tumor cells of various origins, such as the lung (11), colon (12), esophagus (13), liver (14), and stomach (15). The frequency of CHFR methylation varied in each primary tumor. Lung cancer showed $19 \%$ of CHFR methylation, colorectal cancer $26-37 \%$, esophageal cancer $16-24 \%$, hepatocellular cancer $35 \%$, gastric cancers $30-52 \%$. 
However, CHFR was not hypermethylated in ovarian cancer. Moreover, the aberrant methylation of CHFR appears to be a good molecular marker with which to predict the sensitivity of several cancers to microtubule inhibitors $(16,17)$. The loss of CHFR mRNA expression is a consequence of promoter methylation, suggesting a tumor suppressor role for this gene in oral carcinogenesis.

Aurora-A protein kinase is required for the maintenance of spindle bipolarity and the accurate completion of chromosome segregation. A portion of Aurora-A localizes to centrosomes and nearby spindle microtubules, where it rapidly exchanges with cytoplasmic pools. Mechanistically, Aurora-A plays a role in the recruitment and regulation of proteins at centrosomes (18). Aurora-A is located in the $20 \mathrm{q} 13$ breast cancer amplicon and is also overexpressed in colorectal, pancreatic and gastric tumors (19). Aurora-A expression in cancer is often associated with gene amplification, genetic instability, poor histologic differentiation, and poor prognosis (20).

We therefore hypothesize that hypermethylation of CHFR in OSCC could serve as a potential biomarker for clinical diagnosis and monitoring treatment effect. Furthermore, it is not clear wheather in OSCC CHFR works as ubiquitin ligase of Aurora-A in vitro and in human tumor samples. It prompted us to investigate CHFR promoter hypermethylation in OSCC and to clarify the relationship between CHFR methylation and Aurora-A status.

\section{Materials and methods}

Patients and cell lines. Forty-nine primary oral squamous cell carcinomas were collected from patients who underwent surgery at Department of Oral and Maxillofacial Surgery, Gifu University Hospital from 2001 to 2003. Informed consent was obtained from all patients prior to tissue acquisition. The adjacent normal tissue was also collected from surrounding mucosa in 13 out of the 49 OSCC cases. Immediately after resection, the specimens were obtained and snap-frozen at $-20^{\circ} \mathrm{C}$ and stored until use.

Normal oral epithelium was collected from 18 healthy volunteers (mean age: 32.5 years). Six human OSCC cell lines, HSC2, HSC4, SAS, Ca9-22, SCC9 and SCC25 were obtained from Cancer Cell Repository, Tohoku University. These cell lines were maintained in a culture in RPMI-1640 (Sigma, USA) supplemented with $10 \%$ fetal bovine serum in a $5 \% \mathrm{CO}_{2}$ incubator at $37^{\circ} \mathrm{C}$.

DNA extraction and bisulfite modification. Genomic DNA was isolated from tissue specimens and cell lines by standard phenol and chloroform extraction. Sodium bisulfite modification of genomic DNA was performed using the EZ DNA methylation gold kit (Zymo Research, USA), which integrates DNA denaturation and sodium bisulfite modification processes into a single step followed by rapid in-column desulphonation and DNA clean-up, according to the manufacturer's instructions.

Methylation-specific PCR (MSP). Methylation-specific PCR (MSP) was carried out with the following oligonucleotide primers, which were designed to be specific to either methylated or unmethylated DNA after sodium bisulfite modification as described above (11).

Methylated DNA-specific primers were 5'-ATATAAT ATGGCGTCGATC-3' (forward) and 5'-TCAACTAATC CGCGAAACG-3' (reverse). Unmethylated DNA-specific primers were 5'-ATATAATATGGTGTTGATT-3' (forward) and 5'-TCAACTAATCCACAAAACA-3' (reverse). PCR amplification consisted of 1 cycle at $94^{\circ} \mathrm{C}$ for $10 \mathrm{~min}, 40$ cycles of $94^{\circ} \mathrm{C}$ for $1 \mathrm{~min}, 58^{\circ} \mathrm{C}$ for $1 \mathrm{~min}$ and $72^{\circ} \mathrm{C}$ for $1 \mathrm{~min}$ (methylated); and $94^{\circ} \mathrm{C}$ for $1 \mathrm{~min}, 53^{\circ} \mathrm{C}$ for $1 \mathrm{~min}$ and $72^{\circ} \mathrm{C}$ for 1 min (unmethylated).

The resultant PCR products were separated on 3\% agarose gel. CpGenome Universal Methylated DNA (Chemicon International, USA) was used as a positive control, which is enzymatically methylated human male genomic DNA. Normal human blood DNA was used as positive control for unmethylated status.

Real-time PCR (Reverse-transcriptase PCR). Total RNA was isolated from cell lines using TRIzol Reagent (Invitrogen, USA). cDNA was synthesized by using SuperScript III FirstStrand (Invitrogen). Real-time PCR was performed with a Light-Cycler instrument system (Roche, Germany) using SYBR Premix Ex Taq (Takara Biochemicals, Japan) according to the manufacturer's instructions.

CHFR primer sequences were 5'-GAGAGGGGCAGTTT TGCTC-3' (forward) and 5'-CTGTGGTTTTCCCAGCAGCA$3^{\prime}$ (reverse). Aurora-A primer sequences were 5'-GAAGCA ATTGCAGGCAACCA-3' (forward) and 5'-CTTTACCCAG AGGGCGACCA-3' (reverse). GAPDH primer sequences were 5'-TGGTATCGTGGAAGGACTCATGAC-3' (forward) and 5'-ATGCCAGTGAGCTTCCCGTTCAGC-3' (reverse).

The PCR protocol consisted of 1 cycle at $95^{\circ} \mathrm{C}$ for $10 \mathrm{~min}$, 45 cycles at $95^{\circ} \mathrm{C}$ for $10 \mathrm{sec}, 60^{\circ} \mathrm{C}$ for $10 \mathrm{sec}$, and $72^{\circ} \mathrm{C}$ for $6 \mathrm{sec}$. GAPDH was amplified as the internal marker. The expression value of CHFR and Aurora-A was normalized by GAPDH in each cell lines. The relative expression was quantitatively determined.

Immunohistochemistry of Aurora-A. Immunohistochemical staining was carried out with a monoclonal antibody for Aurora-A. It was raised and affinity-purified as described previously (21). Paraffin-embedded sections were dewaxed in xylene and rehydrated in a graded series of ethanol. After blocking endogenous peroxidase and biotin, the sections were incubated overnight with the primary antibody at $4^{\circ} \mathrm{C}$ (the antibody was diluted 100-fold). Next, the sections were incubated with a link anti-mouse and anti-rabbit Ig Dako LSAB2 System, Peroxidase (Dako, Denmark) at room temperature for $10 \mathrm{~min}$ and Streptavidin HRP. Each incubation was followed by 3 washes with PBS. After staining with hematoxylin, the sections were examined under a light microscope.

\section{Results}

Aberrant hypermethylation of CHFR in primary OSCC. Patients clinical characteristics are shown in Table I. In primary OSCC, aberrant promoter hypermethylation of the CHFR gene was detected in $34.7 \%$ (17 of 49). (Fig. 1) The relation among 
Table I. Clinicopathological features and CHFR methylation status of oral squamous cell carcinoma patients.

\begin{tabular}{|c|c|c|c|c|c|c|c|c|}
\hline $\begin{array}{l}\text { Case } \\
\text { no. }\end{array}$ & $\begin{array}{c}\text { CHFR } \\
\text { methylation } \\
\text { status }^{\mathrm{a}}\end{array}$ & Region $^{\mathrm{b}}$ & Histpath $^{\mathrm{c}}$ & $\mathrm{TNM}^{\mathrm{d}}$ & Stage $^{d}$ & Age & Gender & $\begin{array}{c}\text { Lymph } \\
\text { node } \\
\text { metastasis }\end{array}$ \\
\hline 1 & - & Tongue & $\mathrm{SCC}(\mathrm{w})$ & Unknown & Unknown & 70 & M & - \\
\hline 2 & - & Buccal Mucosa & $\mathrm{SCC}(\mathrm{m})$ & T3N0M0 & III & 74 & $\mathrm{M}$ & - \\
\hline 3 & - & Mand. Gingiva & $\mathrm{SCC}(\mathrm{w})$ & T1N0M0 & $\mathrm{I}$ & 71 & $\mathrm{~F}$ & - \\
\hline 4 & - & Maxi. Gingiva & Verrucous & T2NOMO & Unknown & 78 & $\mathrm{~F}$ & - \\
\hline 5 & + & Tongue & $\mathrm{SCC}(\mathrm{w})$ & T2NOM0 & II & 79 & $\mathrm{~F}$ & - \\
\hline 6 & + & Maxi. Gingiva Buccal & $\mathrm{SCC}(\mathrm{w})$ & T3NOM0 & III & 69 & $\mathrm{~F}$ & - \\
\hline 7 & - & Oral floor & $\mathrm{SCC}(\mathrm{w})$ & T4N3M0 & IV B & 70 & $\mathrm{M}$ & + \\
\hline 8 & - & Maxi. Gingiva & $\mathrm{SCC}(\mathrm{w})$ & T4N1M0 & IV A & 75 & M & + \\
\hline 9 & - & Mand. Gingiva & $\mathrm{SCC}(\mathrm{w})$ & T2NOMO & II & 81 & $\mathrm{~F}$ & - \\
\hline 10 & - & Maxi. Gingiva` Buccal & $\mathrm{SCC}(\mathrm{w})$ & T3N0M0 & III & 81 & $\mathrm{M}$ & - \\
\hline 11 & - & Mand. Gingiva & $\mathrm{SCC}(\mathrm{w})$ & T4N0M0 & IV A & 63 & M & - \\
\hline 12 & + & Tongue & $\mathrm{SCC}(\mathrm{m})$ & T3N0M0 & III & 54 & M & - \\
\hline 13 & - & Mand. Gingiva & $\mathrm{SCC}(\mathrm{w})$ & $\mathrm{T} 2 \mathrm{~N} 1 \mathrm{M} 0$ & III & 65 & Unknown & + \\
\hline 14 & - & Tongue & $\mathrm{SCC}(\mathrm{w})$ & T2N0M0 & II & 73 & $\mathrm{~F}$ & - \\
\hline 15 & - & Gingiva Buccal & $\mathrm{SCC}(\mathrm{w})$ & Unknown & Unknown & Unknown & $\mathrm{F}$ & - \\
\hline 16 & - & Tongue & $\mathrm{SCC}(\mathrm{w})$ & T1N0M0 & I & 61 & M & - \\
\hline 17 & - & Mand. Gingiva & $\operatorname{SCC}(w)$ & T2NOMO & II & 75 & $\mathrm{~F}$ & - \\
\hline 18 & + & Mand. Gingiva & $\mathrm{SCC}(\mathrm{m})$ & T4N2bM0 & IV A & 79 & $\mathrm{~F}$ & + \\
\hline 19 & - & Oral floor & $\mathrm{SCC}(\mathrm{m})$ & T2N0M0 & II & 60 & $\mathrm{~F}$ & - \\
\hline 20 & - & Tongue & $\operatorname{SCC}(w)$ & Unknown & Unknown & Unknown & $\mathrm{F}$ & - \\
\hline 21 & + & Buccal Mucosa & $\mathrm{SCC}(\mathrm{w})$ & T4N0M0 & IV A & 86 & $\mathrm{~F}$ & - \\
\hline 22 & - & Mand. Gingiva & $\mathrm{SCC}(\mathrm{w})$ & T3NOM0 & III & 70 & $\mathrm{M}$ & - \\
\hline 23 & + & Mand. Gingiva & $\operatorname{SCC}(w)$ & T3NOM0 & III & 79 & M & - \\
\hline 24 & + & Buccal Mucosa & $\mathrm{SCC}(\mathrm{w})$ & T3NOM0 & III & 79 & $\mathrm{M}$ & - \\
\hline 25 & - & Oral floor & $\mathrm{SCC}(\mathrm{w})$ & T3NOM0 & III & 79 & M & - \\
\hline 26 & + & Mand. Gingiva & $\mathrm{SCC}(\mathrm{w})$ & T4NOMO & IV A & 43 & M & - \\
\hline 27 & - & Maxi. Gingiva & $\mathrm{SCC}(\mathrm{w})$ & T3N2M1 & IV C & 79 & $\mathrm{M}$ & + \\
\hline 28 & + & Mand. Gingiva & $\mathrm{SCC}(\mathrm{w})$ & T3N1M0 & III & 79 & $\mathrm{~F}$ & + \\
\hline 29 & - & Tongue & $\mathrm{SCC}(\mathrm{w})$ & T1N0M0 & $\mathrm{I}$ & 81 & $\mathrm{~F}$ & - \\
\hline 30 & - & Mand. Gingiva & $\mathrm{SCC}(\mathrm{w})$ & T2N1M0 & III & 66 & $\mathrm{M}$ & + \\
\hline 31 & + & Unknown & $\mathrm{SCC}(\mathrm{w})$ & Unknown & Unknown & Unknown & $\mathrm{F}$ & - \\
\hline 32 & - & Tongue & $\mathrm{SCC}(\mathrm{m})$ & T3N1M1 & IV C & 60 & M & + \\
\hline 33 & + & Palate & CIS & TisNOMO & 0 & 69 & $\mathrm{M}$ & - \\
\hline 34 & - & Mand. Gingiva & $\mathrm{SCC}(\mathrm{w})$ & T2N1M0 & III & 73 & $\mathrm{M}$ & + \\
\hline 35 & - & Tongue & $\mathrm{SCC}(\mathrm{w})$ & Unknown & Unknown & Unknown & $\mathrm{F}$ & - \\
\hline 36 & + & Mand. Gingiva & $\mathrm{SCC}(\mathrm{w})$ & T4N2bM0 & IV A & 53 & $\mathrm{~F}$ & + \\
\hline 37 & + & Mand. Gingiva & $\mathrm{SCC}(\mathrm{w})$ & T3N0M0 & III & 85 & $\mathrm{~F}$ & - \\
\hline 38 & + & Buccal Mucosa & $\mathrm{SCC}(\mathrm{w})$ & T1N0M0 & I & 73 & $\mathrm{~F}$ & - \\
\hline 39 & + & Buccal Mucosa & $\mathrm{SCC}(\mathrm{w})$ & T4N0M0 & IV A & 87 & $\mathrm{~F}$ & - \\
\hline 40 & - & Oral floor & CIS & TisNOMO & 0 & Unknown & $\mathrm{M}$ & - \\
\hline 41 & - & Tongue & $\mathrm{SCC}(\mathrm{w})$ & T4N1M0 & IV A & 71 & M & + \\
\hline 42 & - & Oral floor & $\mathrm{SCC}(\mathrm{w})$ & T4NOM0 & IV A & 61 & $\mathrm{M}$ & - \\
\hline 43 & - & Tongue & $\mathrm{SCC}(\mathrm{m})$ & T1N0M0 & I & 79 & $\mathrm{~F}$ & - \\
\hline 44 & + & Unknown & $\operatorname{SCC}(w)$ & Unknown & Unknown & 75 & $\mathrm{~F}$ & - \\
\hline 45 & - & Tongue & $\mathrm{SCC}(\mathrm{w})$ & T2NOM0 & II & 50 & $\mathrm{M}$ & - \\
\hline 46 & - & Tongue & $\mathrm{SCC}(\mathrm{w})$ & T1N0M0 & I & 53 & $\mathrm{M}$ & - \\
\hline 47 & - & Mand. Gingiva & $\operatorname{SCC}(w)$ & T4N0M0 & IV A & 79 & $\mathrm{~F}$ & - \\
\hline 48 & + & Mand. Gingiva & $\mathrm{SCC}(\mathrm{m})$ & T4N1M0 & IV A & 71 & $\mathrm{M}$ & + \\
\hline 49 & - & Buccal Mucosa & $\mathrm{SCC}(\mathrm{m})$ & T4N0M0 & IV A & 62 & $\mathrm{M}$ & - \\
\hline
\end{tabular}

${ }^{\mathrm{a}}+$, methylated; -, unmethylated. ${ }^{\mathrm{b}}$ Maxi., maxillary; Mand., mandibular. ${ }^{\mathrm{c} S C C}(\mathrm{w})$, well-differentiated SCC; SCC (m), moderatelydiferentiated SCC; CIS, carcinoma in situ; Verrucous, verrucous carcinoma. ${ }^{\mathrm{d}}$ TNM and Stage, staged by International Union Against Cancer. ${ }^{\mathrm{e}}+$, with nodal involvement; -, without nodal involvement. 


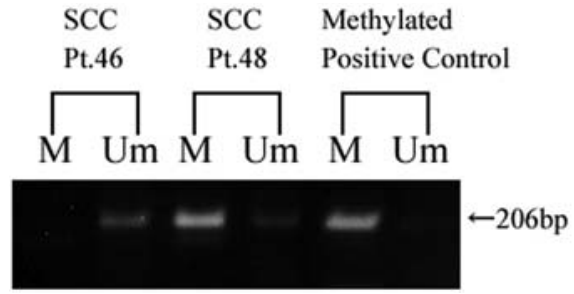

Figure 1. Methylation analysis of CHFR by methylation-specific PCR in primary oral cancer. M, methylated DNA-specific amplification; Um, unmethylated DNA-specific amplification.

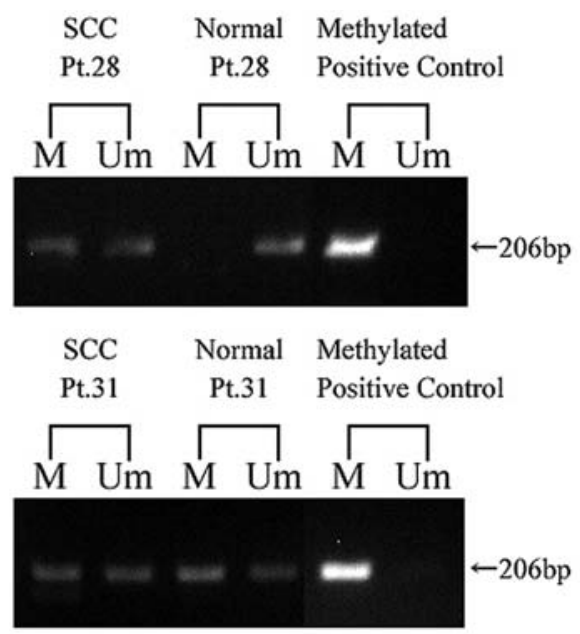

Figure 2. Methylation analysis of CHFR by methylation-specific PCR in primary oral cancer and adjacent normal tissue. M, methylated DNAspecific amplification; Um, unmethylated DNA-specific amplification.

the state of the methylation, clinical stage, tumor size, the part, the lymph node metastasis, gender, and the age is shown in Table II. There was a significant difference between methylated and unmethylated groups regarding tumor size. Moreover, the frequency of CHFR hypermethylation of OSCC in buccal mucosa was significantly higher than in tongue. However, no significant difference was seen in the other clinical features.

As for the 13 OSCC cases with paired cancerous and the adjacent normal tissues, promoter hypermethylation of the CHFR gene was detected in $46.1 \%$ (6 of 13) of the cancerous tissues. This methylation rate is similar to that of overall primary OSCC. In contrast, as for the surrounding normal mucosa, promoter hypermethylation of CHFR gene was recognized only in one case (1 of 13). (Fig. 2 and Table III). As a result, the frequency of the hypermethylation of CHFR in a normal mucosa was extremely lower than primary OSCC. There were no hypermethylation of CHFR gene detected in healthy volunteers.

Aberrant hypermethylation of CHFR in OSCC cell lines and gene expression level of CHFR and Aurora-A. Aberrant promoter hypermethylation of the CHFR gene was detected in Ca9-22 and SCC25 cell lines. Ca9-22 had no unmethylated specific band so that genomic DNA was fully methylated and genomic DNA was partially methylated in SCC25. The CHFR methylation was not detected in other OSCC cell lines (Fig. 3). CHFR promoter hypermethylation was detected in two of six
Table II. CHFR methylation status and clinical variables.

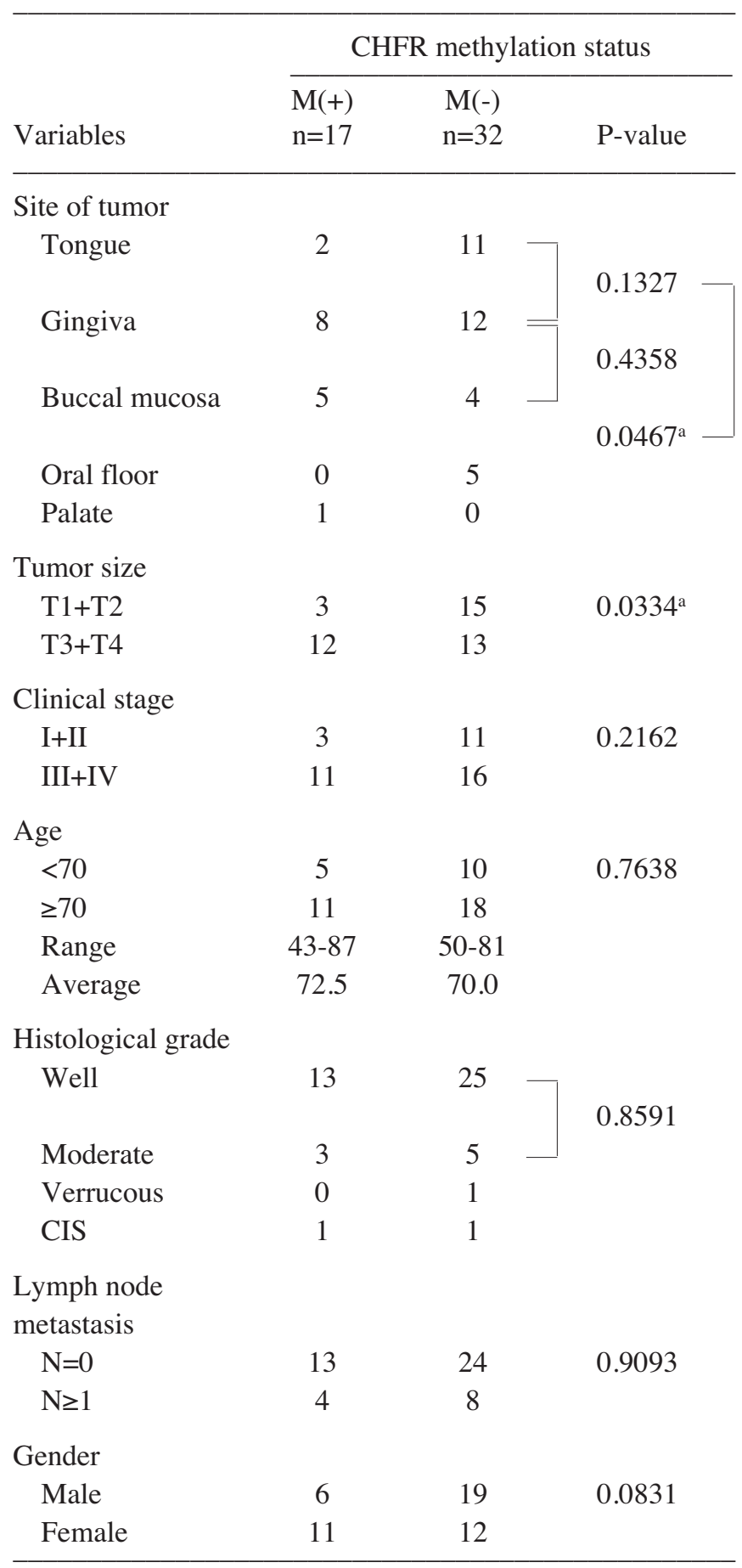

aSignificantlly different by $\chi^{2}$ test.

OSCC cell lines $(33.3 \%)$, so this methylation frequency was in accordance with that of primary OSCC samples.

We performed real-time RT-PCR to assess the mRNA expression level of CHFR and Aurora-A (Fig. 4). CHFR mRNA in Ca9-22 cell line was not expressed by quantitative real-time PCR. The remaining five cell lines showed detectable levels of CHFR mRNA expression. Aurora-A mRNA expression was also detected in all cell lines. There is a dissociation of the expression between CHFR mRNA and Aurora-A mRNA in Ca9-22 cell line. Compared with other 


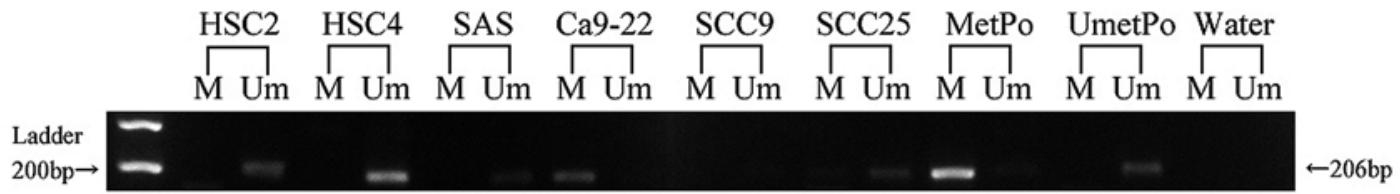

Figure 3. Methylation analysis of CHFR by methylation-specific PCR in OSCC cell lines. M, methylated DNA-specific amplification; Um, unmethylated DNA-specific amplification. MetPo, methylated positive control; UmetPo, unmethylated positive control.

Table III. Methylation status of primary OSCC and adjacent normal tissue.

\begin{tabular}{lcc}
\hline Case no. & Primary OSCC & Normal mucosa \\
\hline 25 & $\mathrm{U}$ & $\mathrm{U}$ \\
26 & $\mathbf{M}$ & $\mathrm{U}$ \\
27 & $\mathrm{U}$ & $\mathrm{U}$ \\
28 & $\mathbf{M}$ & $\mathrm{U}$ \\
29 & $\mathrm{U}$ & $\mathrm{U}$ \\
30 & $\mathbf{M}$ & $\mathrm{U}$ \\
31 & $\mathbf{M}$ & $\mathbf{M}$ \\
32 & $\mathrm{U}$ & $\mathrm{U}$ \\
34 & $\mathrm{U}$ & $\mathrm{U}$ \\
36 & $\mathbf{M}$ & $\mathrm{U}$ \\
37 & $\mathbf{M}$ & $\mathrm{U}$ \\
38 & $\mathbf{M}$ & $\mathrm{U}$ \\
39 & $\mathrm{U}$ & $\mathrm{U}$ \\
\hline
\end{tabular}

M, methylated; U, unmethylated.

cell lines, overexpression of Aurora-A mRNA in Ca9-22 cell line may be influenced by the uncontrolled condition of CHFR.

Immunohistochemistry of Aurora-A in human OSCC samples. Using an affinity-purified polyclonal rabbit antiserum recognizing human Aurora-A protein, a cytoplasmic AuroraA expression was detected in all of the 9 OSCC tumor

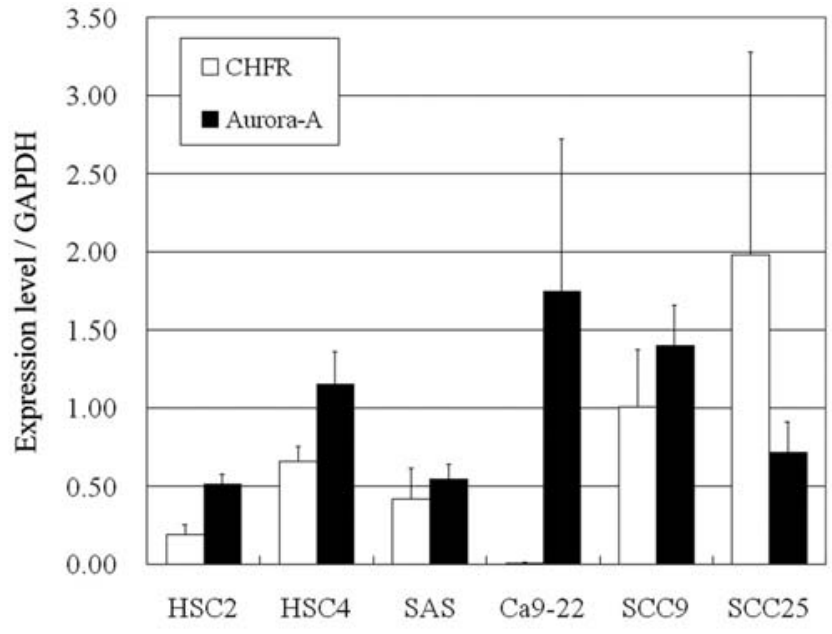

Figuer 4. Quantification of CHFR and Aurora-A mRNA in OSCC cell lines using LightCycler system. Bars indicate expression levels normalized to those of GAPDH. The results are expressed as mean \pm standard deviation.

samples (Table IV). There is no significant difference between Aurora-A expression by immunohistochemistry and CHFR hypermethylation status. All the tumor tissues from OSCC showed positive staining of Aurora-A in their cytoplasm independent of CHFR hypermethylation status.

\section{Discussion}

In the present study, the frequency of CHFR methylation varies in different sites compared to other organs primary

Table IV. Immunohistchemical staining status of Aurora-A.

\begin{tabular}{|c|c|c|c|c|c|}
\hline \multirow[b]{2}{*}{ Case no. } & \multirow[b]{2}{*}{ CHFR status } & \multirow[b]{2}{*}{ Region } & \multirow[b]{2}{*}{ Histopathology } & \multicolumn{2}{|c|}{ Aurora-A staining } \\
\hline & & & & Cytoplasma & Nuclear \\
\hline 22 & U & Gingiva & $\mathrm{SCC}(\mathrm{w})$ & + & - \\
\hline 23 & M & Gingiva & SCC(w) & ++ & + \\
\hline 24 & M & Buccal mucosa & $\mathrm{SCC}(\mathrm{w})$ & ++ & + \\
\hline 25 & $\mathrm{U}$ & Oral floor & SCC(w) & ++ & \pm \\
\hline 29 & $\mathrm{U}$ & Tongue & $\mathrm{SCC}(\mathrm{w})$ & + & - \\
\hline 30 & $\mathrm{U}$ & Gingiva & SCC(w) & +++ & - \\
\hline 32 & $\mathrm{U}$ & Tongue & $\mathrm{SCC}(\mathrm{m})$ & ++ & - \\
\hline 36 & M & Gingiva & $\mathrm{SCC}(\mathrm{w})$ & ++ & + \\
\hline 38 & M & Buccal mucosa & $\mathrm{SCC}(\mathrm{w})$ & + & + \\
\hline
\end{tabular}

M, methylated; U, unmethylated. SCC(w), well-differentiated SCC; SCC (m), moderately-diferentiated SCC. 
tumor. For example, nasopharyngeal carcinoma has high frequency of CHFR methylation at $61.1 \%$ (22). In contrast, breast cancer has low level of CHFR methylation at $0.9 \%$ (23) and ovarian cancer has no methylation (24). CHFR promoter hypermethylation of primary OSCC was $34.7 \%$ in our study. In primary head and neck squamous cell carcinomas, the frequency of CHFR methylation has been reported to be $\sim 30 \%$ (25) and 25\% (26). These results were consistent with our data.

Regarding the relationship between CHFR methylation and clinicopathological characteristics, our results indicate that the frequency of CHFR methylation occurs in T3-T4 squamous cell carcinoma was significantly higher than in T1T2 squamous cell carcinoma. Thus, our results imply that the OSCCs in advanced stage have more frequent methylation in the promoter region of CHFR. It was also reported that the methylation of CHFR is seen only in the stage IV case of head and neck cancer (26). Therefore, when the cancer progresses, CHFR methylation occurs with high frequency. Moreover, our results indicate CHFR methylation occurs in buccal mucosa SCC significantly more frequently than in tongue SCC. Thus, location-specific occurrence of CHFR methylation is considered in OSCC.

It has also been reported that CHFR methylation correlated to its differentiation of the tumor histology for endometrium cancer (16). Our results, however, shows no relationship between the CHFR methylation status and differentiation degree of the SCC histology. A significant difference according to gender has been reported, female esophageal cancers were more frequently methylated than male (27). Our results also showed a tendency of CHFR methylation in female more frequently than male. The relationship between CHFR expression and clinical characteristics may be different among cancer types. As a result of CHFR methylation, mRNA expression of CHFR is silenced. In breast cancer, it has been reported that there is an association between CHFR mRNA expression and the tumor size (28) and it is in agreement with our data. Previous studies have revealed that the loss of CHFR expression by aberrant methylation may predict the responsiveness of human cancers to microtubule inhibitors such as taxane (29). Cancer cells silencing CHFR are sensitive to microtubule inhibitors, which are considered as a result from impaired checkpoint function. Therefore, the detection of CHFR methylation status may be used in clinical application and in curative effect judgment.

As for DNA methylation of other tumor supressor genes in OSCC, various genes have been investigated previously. CHFR is one of the cell cycle regulatory genes. The other cell cycle regulating genes such as p15 and p16 (4) have been extensively studied and the promoter hypermethylation is common in OSCC, however no significant correlation with clinicopathological characteristics or prognosis has been observed. In contrast, p14 hypermethylation has been related to good prognosis in two studies $(30,31)$. Moreover, E-cadherin hypermethylation was $\sim 50 \%$ and it was related to histological grade and poor survival (32). There was hypermethylation in $27 \%$ of DAPK, a gene that takes part in apoptosis, and its hypermethylation is related to the metastasis in lymph nodes (33). Hypermethylation of the RECK gene is $\sim 50 \%$ in the cancerous tissue and is correlated with recurrence-free survival and overall survival (34). In contrast, MGMT, a DNA-repair gene, has high frequency of hypermethylation with $50 \%$ or more but there is no significant relation with clinicopathological characteristics (35).

In this study, we showed that the promoter hypermethylation of the CHFR gene occurred frequently in the primary cancerous tissues but rarely in the adjacent normal mucosa. As a result, hypermethylation of CHFR in the surrounding normal tissue of only one case is concurrent with in the cancerous tissue of the same patient. There was no case showing hypermethylation only in the normal tissues. The concept of 'Field Cancerization' that Slaughter advocated in OSCC in 1953 (36) became an important mechanism in permeation and metastasis. Field cancerization takes part in the formation of second primary tumor (37) and is important in the secondary expansion of the tumor. Methylation of CHFR in the surrounding normal tissue was rare in our results and the concept of 'Field cancerization' is not reflected in CHFR methylation in the occurrence of OSCC. However, there were several studies on high frequency of DNA methylation in certain tumor suppressor or related genes such as p16, MGMT (35), and RECK (34) detected in surrounding normal tissues associated with cancerous tissue. Further work is needed to clarify this concept for field cancerization of OSCC.

It is well accepted that CHFR works as a ubiquitin ligase of Aurora-A and it has been reported that CHFR regulates Aurora-A (9). However, this relationship was not confirmed by our investigation. CHFR hypermethylation is common even in primary OSCC tumors but not in surrounding normal mucosa whereas Aurora-A gene expression seems to be independent from methylation status and mRNA expression of the CHFR gene in OSCC. Additional study is required to determine the potential contribution of the CHFR promoter hypermethylation in oral carcinogenesis.

\section{Acknowledgements}

The authors are indebted to Ms. K. Takahashi and Mr. K. Kinjo for her excellent technical assistance.

\section{References}

1. Chen JK, Katz RV and Krutchkoff DJ: Intraoral squamous cell carcinoma. Epidemiologic patterns in Connecticut from 1935 to 1985. Cancer 66: 1288-1296, 1990.

2. WHO: Global Data on Incidence of Oral Cancer. World Health Organization, 2005.

3. Kato H, Sobue T, Katanoda K, et al (eds): Cancer Statistics in Japan. The Editorial Board of Cancer Statistics in Japan, Tokyo, pp60-68, 2007.

4. Shaw R: The epigenetics of oral cancer. Int J Oral Maxillofac Surg 35: 101-108, 2006.

5. Ha PK and Califano JA: Promoter methylation and inactivation of tumour-suppressor genes in oral squamous-cell carcinoma. Lancet Oncol 7: 77-82, 2006.

6. Cahill DP, Lengauer C, Yu J, et al: Mutations of mitotic checkpoint genes in human cancers. Nature 392: 300-303, 1998.

7. Scolnick DM and Halazonetis TD: Chfr defines a mitotic stress checkpoint that delays entry into metaphase. Nature 406: 430-435, 2000.

8. Kang D, Chen J, Wong J and Fang G: The checkpoint protein $\mathrm{Chfr}$ is a ligase that ubiquitinates Plk1 and inhibits $\mathrm{Cdc} 2$ at the G2 to M transition. J Cell Biol 156: 249-259, 2002. 
9. Yu X, Minter-Dykhouse K, Malureanu L, et al: Chfr is required for tumor suppression and Aurora A regulation. Nat Genet 37: 401-406, 2005

10. Strebhardt $\mathrm{K}$ and Ullrich A: Targeting polo-like kinase 1 for cancer therapy. Nat Rev Cancer 6: 321-330, 2006.

11. Mizuno K, Osada H, Konishi H, et al: Aberrant hypermethylation of the CHFR prophase checkpoint gene in human lung cancers. Oncogene 21: 2328-2333, 2002.

12. Corn PG, Summers MK, Fogt F, et al: Frequent hypermethylation of the $5^{\prime} \mathrm{CpG}$ island of the mitotic stress checkpoint gene $\mathrm{Chfr}$ in colorectal and non-small cell lung cancer. Carcinogenesis 24 : 47-51, 2003

13. Hamilton JP, Sato F, Greenwald BD, et al: Promoter methylation and response to chemotherapy and radiation in esophageal cancer. Clin Gastroenterol Hepatol 4: 701-708, 2006.

14. Sakai M, Hibi K, Kanazumi N, et al: Aberrant methylation of the CHFR gene in advanced hepatocellular carcinoma. Hepatogastroenterology 52: 1854-1857, 2005.

15. Kang HC, Kim IJ, Park JH, et al: Promoter hypermethylation and silencing of CHFR mitotic stress checkpoint gene in human gastric cancers. Oncol Rep 12: 129-133, 2004

16. Yanokura M, Banno K, Kawaguchi M, et al: Relationship of aberrant DNA hypermethylation of CHFR with sensitivity to taxanes in endometrial cancer. Oncol Rep 17: 41-48, 2007.

17. Satoh A, Toyota M, Itoh F, et al: Epigenetic inactivation of CHFR and sensitivity to microtubule inhibitors in gastric cancer. Cancer Res 63: 8606-8613, 2003

18. Liu Q and Ruderman JV: Aurora A, mitotic entry, and spindle bipolarity. Proc Natl Acad Sci USA 103: 5811-5816, 2006.

19. Barr AR and Gergely F: Aurora-A: the maker and breaker of spindle poles. J Cell Sci 120: 2987-2996, 2007.

20. Gautschi O, Heighway J, Mack PC, Purnell PR, Lara PN Jr and Gandara DR: Aurora kinases as anticancer drug targets. Clin Cancer Res 14: 1639-1648, 2008.

21. Kimura M, Kotani S, Hattori T, et al: Cell cycle-dependent expression and spindle pole localization of a novel human protein kinase, Aik, related to Aurora of Drosophila and yeast Ipl1. J Biol Chem 272: 13766-13771, 1997.

22. Cheung HW, Ching YP, Nicholls JM, et al: Epigenetic inactivation of CHFR in nasopharyngeal carcinoma through promoter methylation. Mol Carcinog 43: 237-245, 2005.

23. Tokunaga E, Oki E, Nishida K, et al: Aberrant hypermethylation of the promoter region of the CHFR gene is rare in primary breast cancer. Breast Cancer Res Treat 97: 199-203, 2006.

24. Ludwig AH, Bujko M, Bidzinski M and Kupryjanczyk J: CHFR gene is neither mutated nor hypermethylated in ovarian cancer. Cancer Detect Prev 31: 257-261, 2007.

25. Toyota M, Sasaki Y, Satoh A, et al: Epigenetic inactivation of CHFR in human tumors. Proc Natl Acad Sci USA 100: 7818-7823, 2003.
26. Chen K, Sawhney R, Khan M, et al: Methylation of multiple genes as diagnostic and therapeutic markers in primary head and neck squamous cell carcinoma. Arch Otolaryngol Head Neck Surg 133: 1131-1138, 2007.

27. Morioka Y, Hibi K, Sakai M, et al: Aberrant methylation of the CHFR gene in digestive tract cancer. Anticancer Res 26: 1791-1795, 2006

28. Privette LM, Gonzalez ME, Ding L, Kleer CG and Petty EM: Altered expression of the early mitotic checkpoint protein, CHFR, in breast cancers: implications for tumor suppression. Cancer Res 67: 6064-6074, 2007.

29. Koga Y, Kitajima Y, Miyoshi A, Sato K, Sato S and Miyazaki K: The significance of aberrant CHFR methylation for clinical response to microtubule inhibitors in gastric cancer. J Gastroenterol 41: 133-139, 2006.

30. Sailasree R, Abhilash A, Sathyan KM, Nalinakumari KR, Thomas S and Kannan S: Differential roles of p16INK4A and p14ARF genes in prognosis of oral carcinoma. Cancer Epidemiol Biomarkers Prev 17: 414-420, 2008.

31. Ogi K, Toyota M, Ohe-Toyota M, et al: Aberrant methylation of multiple genes and clinicopathological features in oral squamous cell carcinoma. Clin Cancer Res 8: 3164-3171, 2002.

32. Chang HW, Chow V, Lam KY, Wei WI and Yuen A: Loss of E-cadherin expression resulting from promoter hypermethylation in oral tongue carcinoma and its prognostic significance. Cancer 94: 386-392, 2002.

33. Sanchez-Cespedes M, Esteller M, Wu L, et al: Gene promoter hypermethylation in tumors and serum of head and neck cancer patients. Cancer Res 60: 892-895, 2000.

34. Long NK, Kato K, Yamashita T, et al: Hypermethylation of the RECK gene predicts poor prognosis in oral squamous cell carcinomas. Oral Oncol 44: 1052-1058, 2008.

35. Kato K, Hara A, Kuno T, et al: Aberrant promoter hypermethylation of p16 and MGMT genes in oral squamous cell carcinomas and the surrounding normal mucosa. J Cancer Res Clin Oncol 132: 735-743, 2006.

36. Slaughter DP, Southwick HW and Smejkal W: Field cancerization in oral stratified squamous epithelium; clinical implications of multicentric origin. Cancer 6: 963-968, 1953.

37. Braakhuis BJ, Tabor MP, Leemans CR, van der Waal I, Snow GB and Brakenhoff RH: Second primary tumors and field cancerization in oral and oropharyngeal cancer: molecular techniques provide new insights and definitions. Head Neck 24: 198-206, 2002. 